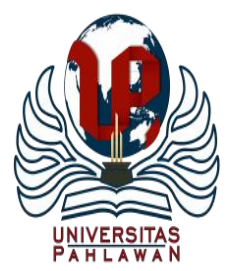

Edukatif : Jurnal Ilmu Pendidikan Volume 3 Nomor 3 Tahun 2021 Halm 758 - 769

EDUKATIF: JURNAL ILMU PENDIDIKAN

Research \& Learning in Education

https:/ledukatif.org/index.php/edukatif/index

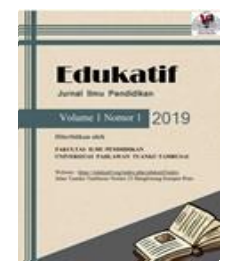

\title{
Analisis Kecemasan Akademis Melalui Self Efficacy dan Dukungan Sosial pada Siswa SMK Jurusan Akuntansi
}

\author{
Shabilla Yasmin Priyanti ${ }^{1 凶}$, Mardi $^{2}$, Achmad Fauzi $^{3}$ \\ Universitas Negeri Jakarta, Indonesia ${ }^{1,2,3}$ \\ E-mail : $\underline{\text { shabillayasmin1@gmail.com }}{ }^{1}, \underline{\text { mardi@ } @ \text { unj.ac.id }}^{2}, \underline{\text { fau smart@ unj.ac.id }}^{3}$
}

\begin{abstract}
Abstrak
Penelitian diawali munculnya masalah kecemasan akademis pada siswa di SMK Akuntansi, akibat perubahan proses pembelajaran selama COVID 19 dan bersamaan menumpuknya tugas sekolah. Tujuan penelitian ialah menganalisis kecemasan akademis melalui self efficacy dan dukungan sosial pada siswsa kelas XII Akuntansi. Pendekatan yang digunakan merupakan pendekatan kuantitatif dan menggunakan metode survei, data dikumpulkan menggunakan kuesioner dengan skala Likert. Sampel menggunakan 103 siswa dengan teknik proportional random sampling. Data penelitian di analisis dengan SPSS versi 27. Hasil uji-T menggambarkan self efficacy dan dukungan sosial berpengaruh negatif signifikan terhadap kecemasan akademis secara parsial. Sedangkan menggunakan uji-F disimpulkan self efficacy dan dukungan sosial berpengaruh signifikan terhadap kecemasan akademis secara simultan. Self efficacy dan dukungan sosial memiliki kontribusi 46,6\% untuk memprediksi kecemasan akademis. Penelitian ini berkontribusi terhadap pembuktian secara empiris mengenai pengaruh self efficacy dan dukungan sosial dengan kecemasan akademis yang dialami peserta didik.
\end{abstract}

Kata Kunci: Self efficacy, kecemasan akademis, dukungan sosial, bidang akuntansi, sekolah menengah kejuruan.

\begin{abstract}
This study is initialized by the emerge of academic anxiety among vocational high school students in accounting field because of the changes of learning process due to COVID 19 and excessive school tasks. This study aims to analize academic anxiety through self efficacy and social support of grade XII accounting students. This study uses quantitative approach and survey method, and data are collected by questionnaire with likert scales. The samples are 103 students and use proportional random sampling technique. The data are analized by SPSS application Version 27. Based on the T test, indicates that Self efficacy and social support has a significant negative effect on academic anxiety partially. Meanwhile, based on the F test, Self efficacy and social support has a significant effect on academic anxiety simultaneously. Self efficacy and social support have a contribution of $46.6 \%$ to predict the academic anxiety. This study has contribution to prove empirically about the effect of Self efficacy and social support on academic anxiety of grade XII accounting student.
\end{abstract}

Keywords: Self efficacy, social support, academic anxiety, accounting department, vocational senior high school.

Copyright (c) 2021 Shabilla Yasmin Priyanti, Mardi, Achmad Fauzi

$\triangle$ Corresponding author

Email : shabillayasmin1@gmail.com

DOI : https://doi.org/10.31004/edukatif.v3i3.440

ISSN 2656-8063 (Media Cetak)

ISSN 2656-8071 (Media Online)

Edukatif : Jurnal Ilmu Pendidikan Vol 3 No 3 Tahun 2021

p-ISSN 2656-8063 e-ISSN 2656-8071 


\section{PENDAHULUAN}

Menciptakan bangsa yang bermartabat merupakan hasil dari proses pendidikan yang dijalani (Sutarsyah, 2016). Makna dari pendidikan yaitu upaya untuk mengembangkan setiap potensi namun masih berpedoman dengan nilai-nilai dan budaya yang tumbuh dalam masyarakat (Anwar, 2015). Sama halnya di Indonesia yang memiliki banyak keanekaragaman budaya, maka dalam pengembangannya pendidikan perlu memperhatikan keanekaragaman tersebut sebagai kerangka sistem pendidikan yang akan diberlakukan (Hanani, 2017).

Pemerintah Indonesia harus berupaya untuk terus mengembangkan pendidikan mengikuti perkembangan teknologi dan ilmu pengetahuan yang bukan hanya mewarisi budaya lama, namun menciptakan individu yang mampu hidup dari masa ke masa (Iriana, 2016). Namun terlepas dari itu, kondisi pendidikan yang terjadi justru mengatakan sebaliknya. Berdasarkan hasil survei oleh PISA (Programme International Student Assessment) tahun 2018 (OECD, 2018), pendidikan di Indonesia menempati peringkat ke-72 dari 77 negara. Kondisi tersebut semakin diperburuk dengan situasi di awal tahun 2020 yaitu adanya persebaran wabah COVID-19. Fenomena COVID 19 berdampak pada penyelenggaraan pendidikan, dimana pemerintah mencari berbagai cara sehingga kegiatan belajar berjalan tanpa siswa datang ke sekolah (Mansyur, 2020). Kebijakan yang dikeluarkan oleh pemerintah dalam bentuk Pembatasan Sosial Bersekala Besar (PSBB) membuat kegiatan pembelajaran di sekolah dialihkan ke rumah, belajar melalui media daring (Syah, 2020).

Pembelajaran tersebut menyebabkan peserta didik dituntut untuk belajar lebih kreatif secara mandiri (Anshori \& Illiyyin, 2020). Namun yang perlu menjadi perhatian dari tenaga pendidik maupun satuan pemerintah di bidang pendidikan adalah ada beberapa peserta didik yang kesulitan dalam beradaptasi dan menghambat daya serap belajar peserta didik (Dewi, 2020). Menurut (Jatira \& Neviyarni, 2021) adanya perubahan pada lingkungan, suasana, dan kurikulum pembelajaran menjadi penyebab dalam timbulnya stres akademis. Pembelajaran jarak jauh yang diterapkan membuat beban tugas mereka lebih banyak. Menurut KPAI (Komisi Perlindungan Anak Indonesia) bahwa ada sebanyak 44,1\% peserta didik yang menghabiskan 1 3 jam untuk mengerjakan tugas, 34,2\% yang menghabiskan 3-6 jam, dan 21,6\% yang menghabiskan lebih dari 6 jam. KPAI juga menyatakan bahwa ada sekitar 73,2\% peserta didik yang mengaku merasa berat dalam mengerjakan tugas (KPAI, 2020). Tugas yang berlebih tersebut dapat membuat peserta didik mengalami kurang istirahat dan kualitas tidur yang menurun. Hal ini bisa menyebabkan mereka mengalami gangguan kecemasan (Fitria \& Ifdil, 2020). Kurangnya pemahaman terhadap materi juga membuat peserta didik kesulitan dalam mengerjakan tugas, sehingga dapat menyebabkan kecemasan akademis (Oktawirawan, 2020).

Penelitian (Ardianto, 2018) menyimpulkan kecemasan yang dirasakan oleh peseta didik dapat membuat mereka sulit untuk berkonsentrasi terutama saat akan menghadapi ujian. Selain itu mereka sulit berkonsentrasi saat melakukan kegiatan belajar, hilang kendali akan diri sendiri, sering melamun, dan banyak khawatir mengenai masa depan. Kecemasan ini mengganggu keadaan fisik mereka serta membuat mereka sulit melakukan kegiatan pembelajaran. Hal ini juga dijelaskan pada penelitian (Syamsurijal \& Sarwan, 2021) bahwa kondisi psikologis peserta didik yang kurang baik akibat pembelajaran selama pandemi menyebabkan mereka cenderung ingin pembelajaran daring tersebut segera berakhir. Kecemasan akademis yang dialami oleh peserta didik diduga dapat diatasi bila Self efficacy yang dimiliki tinggi. Penelitian (Mugiarso et al., 2018) menyimpulkan kecemasan yang dirasakan peserta didik memiliki hubungan dengan Self efficacy apabila dilihat dari kemampuan peserta didik mengatasi situasi sulit. Apabila peserta didik memiliki Self efficacy tinggi cenderung memiliki kecemasan yang rendah menjalani tugasnya. Penelitian yang dilakukan oleh (Qudsyi \& Putri, 2016) mengatakan semakin tinggi tingkat Self efficacy peserta didik, maka peserta didik akan merasakan kecemasan akademis yang lebih rendah terutama kecemasan dalam menghadapi ujian.

Selain Self efficacy peserta didik, dukungan sosial yang diterima oleh peserta didik pun diduga dapat menurunkan kecemasan akademis yang dirasakan oleh mereka. Penelitian (Sri Djuwitawati \& Djalali, 2015) 
menyimpulkan dukungan sosial dapat menurunkan kecemasan akademis dan meningkatkan kepercayaan diri peserta didik. Dukungan berupa dukungan orang tua, guru, ataupun bimbingan konseling yang disediakan sekolah. Penelitian (Brailovskaia et al., 2018) mengatakan untuk mengatasi masalah kesehatan mental diperlukan faktor eksternal maupun internal. Faktor eksternal dapat berupa dukungan sosial dari orang-orang sekitar. Peserta didik yang didukung secara sosial cenderung terhindar dari depresi, kecemasan, dan juga stres.

Terkait topik kecemasan akademis, Self efficacy, dan dukungan sosial ini penting diteliti. Hal ini didasarkan pada (Habibullah et al., 2019) yang mengatakan bahwa kekhawatiran dan juga ketakutan yang dirasakan peserta didik dapat menyebabkan kecemasan. Kecemasan tersebut membuat peserta didik cenderung menghindari tugas sekolahnya, bahkan tidak mengerjakannya sehingga tugas tersebut tidak akan selesai. (Chou, 2019) menyatakan bahwa Self efficacy penting dimiliki peserta didik terutama untuk memilih kegiatannya, sehingga mereka dapat menghadapi situasi yang baru. Menurut (Reid et al., 2016) persepsi mengenai dukungan sosial juga penting untuk diteliti karena dukungan sosial memiliki potensi untuk melindungi kesehatan mental peserta didik. Dalam (Andarini, 2020) menjelaskan dukungan sosial dari orang tua dan juga Self efficacy peserta didik berpengaruh signifikan pada stres akademis. Peserta didik dengan Self efficacy yang tinggi cenderung mengurangi stres yang dialami dan meningkatkan hasil belajar, mereka juga lebih tekun, mampu mengolah emosi, mengatasi masalah serta mengatasi tekanan. Dukungan sosial dari orang tua yang tinggi membuat peserta didik merasa dipedulikan sehingga emosi mereka lebih stabil menghadapi kesulitan akademis.

Namun (Herawati et al., 2021) mengatakan dukungan sosial memiliki peran besar mengurangi kecemasan akademis peserta didik dibanding Self efficacy. Kesimpulan berbeda dengan (Situmorang, 2019) yang menyatakan dukungan sosial justru tidak memberikan pengaruh besar mengurangi kecemasan, dukungan ini hanya akan berpengaruh pada Self efficacy peserta didik. Kecemasan akademis dalam (Ardianto, 2018; Oktawirawan, 2020; Stewart et al., 2015) dijelaskan sebagai keadaan emosi yang terjadi akibat ketakutan akan kegagalan serta adanya ketidaksamaan antara harapan dan realita akademis. Kecemasan ini timbul akibat kurangnya penguasaan materi dan juga ancaman harga diri peserta didik. Menurut (Suputra \& Susilawati, 2019) kecemasan akademis ini dapat mempengaruhi cara belajar, motivasi, nilai, serta kemampuan di masa depan peserta didik. Kecemasan akademis bisa disebabkan karena ketakutan terhadap masa depan yang tidak pasti yang akan mengganggu pola pikir dan perilaku akibat pressure yang dirasakan selama mengerjakan tugas dan aktivitas akademis.

Menurut (Ardianto, 2018; Huerta et al., 2017; Suputra \& Susilawati, 2019), kecemasan akademis membuat terganggunya pola pikir dan hilangnya kesenangan saat proses pembelajaran akibat kekhawatiran pada kejadian dimasa depan. Akibat dari kecemasan akademis yang dirasakan peserta didik sulit berkonsentrasi, memecahkan masalah, mengingat sesuatu, dan menurunnya kemampuan peserta didik. Self efficacy merupakan kepercayaan seseorang pada kemampuannya menyelesaikan tugas dan mencapai tujuan tertentu yang dapat mempengaruhi pola pikir, motivasi diri, dan perilakunya (Raharjayanti, 2019; Sari \& Sumiati, 2016; Wagetama et al., 2017). Self efficacy membuat peserta didik dapat meningkatkan usaha yang diberikannya untuk mencapai tujuan, mengatur kegiatan belajarnya secara mandiri, dan memenuhi harapan akademis dirinya dan orang lain (Safiany \& Maryatmi, 2018; Sagita et al., 2017).

Menurut (Rambe, 2017) self efficacy dapat mempengaruhi cara seseorang berperilaku. Jika seseorang yakin pada kemampuannya dalam menghasilkan sesuatu maka mereka cenderung berusaha untuk mencapai tujuannya. Selain itu seseorang dengan self efficacy yang tinggi cenderung menganggap kesulitan tugas sebagai suatu tantangan. Dalam (Iswahyudi et al., 2019) menjelaskan Self efficacy membuat seseorang menjadi lebih percaya diri dengan kemampuannya sehingga mereka cenderung akan memberikan pengetahuan baru, sikap, dan juga keterampilan. Seseorang dengan self efficacy tinggi cenderung memiliki kinerja yang lebih optimal meskipun dalam tekanan. Mereka akan lebih mudah beradaptasi dan belajar. 
Dukungan sosial adalah dukungan secara emosional dan secara instrumental dari hubungan sosial yang berkualitas (Liu, 2019). Dukungan sosial membuat seseorang merasa nyaman dengan orang-orang disekitarnya dan merasa seperti berada di rumah kedua (McDonnell, 2014). Dukungan sosial adalah kepedulian yang timbul dari hubungan yang baik dengan orang lain baik keluarga, teman, dan pihak lain. Dukungan sosial dapat membantu mengurangi masalah psikologis karena individu cenderung merasa dicintai. Individu yang memiliki hubungan baik dengan orang-orang disekitarnya dapat menghadapi masalahnya dengan baik dan meningkatkan kemampuan dirinya (Cintya \& Supriyadi, 2020; Halim, 2019; Prayogi et al., 2017). Menurut (LAM, 2019) dukungan sosial adalah komunikasi verbal maupun non verbal untuk mengurangi perasaaan ketidakpastian mengenai situasi, diri sendiri, hubungan, orang lain, dan fungsi untuk meningkatkan kontrol diri pada pengalaman seseorang.

Berbeda dari penelitian relevan terdahulu, periode pengambilan data pada penelitian ini dilakukan ketika peserta didik telah merasakan proses distance learning, dimana pada proses pembelajaran ini cenderung terjadi kecemasan akademis yang tinggi. Selain itu populasi yang digunakan adalah peserta didik kelas XII akuntansi, sehingga penelitian ini menjadi pembuktian apakah pengaruh self efficacy dan dukungan sosial terhadap kecemasan akademis berlaku pada siswa di bidang akuntansi. Hal tersebut yang menjadi kebaruan dalam penelitian ini.

Penelitian ini menganalisis kecemasan akademis melalui self efficacy dan dukungan sosial pada siswa. Kecemasan akademis merupakan masalah yang sering dialami dan dapat mengganggu konsentrasi peserta didik. Lebih jauh hasil penelitian digunakan untuk mengembangkan kemampuan akademis sebagai upaya menyiapkan tenaga terampil yang dihasilkan pada SMK jurusan Akuntansi. Dengan demikian masalah pokok penelitian ini adalah apakah kecemasan akademis dipengaruhi oleh self efficacy dan dukungan sosial pada siswa SMK Jurusan Akuntansi?

\section{METODE PENELITIAN}

Penelitian ini menggunakan metode kuantitatif, unit analisis adalah siswa kelas XII akuntansi (SMKN 1 Bogor dan SMKN 2 Cibinong) sebanyak 139 orang. Teknik yang digunakan adalah proportional random sampling, besar sampel yaitu 103 siswa, selanjutnya data dikumpulkan menggunakan kuesioner (Kurniawan \& Puspitaningtyas, 2016). Kuesioner diukur menggunakan skala likert (Syahrum \& Salim, 2014). Validitas kuesioner diuji dengan product moment, sedangkan reliabilitas kuesioner diuji menggunakan Alpha Cronbach, kesimpulan menunjukkan angket yang digunakan valid dan reliabel. Pengolahan data penelitian menggunakan SPSS versi 27. Dengan tahapan pengujian menghitung persamaan regresi berganda, pengujian persyaratan analisis (normalitas dan linearitas), kemudian dilakukan uji hipotesis serta analisis koefisien determinan.

\section{HASIL DAN PEMBAHASAN}

Hasil pengolahan data kuesioner yang disebarkan kepada 103 siswa kelas XII akuntansi, diperoleh data statistik deskriptif yaitu:

Tabel 1. Deskripsi Statistik Data

\begin{tabular}{|l|c|c|c|c|c|}
\hline & N & Min & Max & Mean & Std \\
\hline Kecemasan akademis & 103 & 39 & 61 & 48.97 & 5.079 \\
\hline Self efficacy & 103 & 34 & 51 & 42.17 & 3.787 \\
\hline Dukungan Sosial & 103 & 35 & 56 & 44.12 & 4.863 \\
\hline
\end{tabular}


762 Analisis Kecemasan Akademis Melalui Self Efficacy dan Dukungan Sosial pada Siswa SMK Jurusan Akuntansi - Shabilla Yasmin Priyanti, Mardi, Achmad Fauzi

DOI: https://doi.org/10.31004/edukatif.v3i3.440

Tabel. 1 mengambarkan kecemasan akademis memiliki rata-rata 48.97 dengan standar deviasi 5.079, self efficacy memiliki rata-rata 42.17 dengan standar deviasi 3.787, dan dukungan sosial memiliki rata-rata 44.12 dengan standar deviasi 4.863. Berdasarkan deskripsi data di atas, sebanyak 103 siswa dikategorikan sebagai berikut:

Tabel 2. Kategorisasi Sampel

\begin{tabular}{|c|c|c|c|c|c|c|c|}
\hline & \multicolumn{2}{|c|}{ Kecemasan Akademis } & \multicolumn{2}{|c|}{ Self Efficacy } & \multicolumn{2}{|c|}{ Dukungan Sosial } \\
\hline & & Frequency & Percent & Frequency & Percent & Frequency & Percent \\
\hline \multirow{4}{*}{ Valid } & Rendah & 13 & 12.4 & 21 & 20.0 & 15 & 14.3 \\
\hline & Sedang & 73 & 69.5 & 61 & 58.1 & 69 & 65.7 \\
\hline & Tinggi & 17 & 16.2 & 21 & 20.0 & 19 & 18.1 \\
\hline & Total & 103 & 98.1 & 103 & 98.1 & 103 & 98.1 \\
\hline Missing & System & 2 & 1.9 & 2 & 1.9 & 2 & 1.9 \\
\hline \multicolumn{2}{|c|}{ Total } & 105 & 100.0 & 105 & 100.0 & 105 & 100.0 \\
\hline
\end{tabular}

Sumber: hasil pengolahan data peneliti

Tabel. 2 menunjukkan sebanyak 17 siswa mengalami kecemasan akademis tinggi (16.2\%), dan 73 siswa mengalami kecemasan akademis sedang (69.5\%), 13 siswa mengalami kecemasan akademis rendah (12.4\%). Selanjutnya sebanyak 21 siswa dengan Self efficacy yang rendah (20\%), dan 61 siswa dengan Self efficacy sedang (58.1\%), ada 21 siswa memiliki Self efficacy tinggi (20\%). Kemudian 15 siswa mendapat dukungan sosial yang rendah (14.3\%), 69 siswa mendapat dukungan sosial sedang (65.7\%), dan sebanyak 19 siswa mendapat dukungan sosial tinggi (18.1\%).

Tabel 3. Persamaan Regresi Berganda

\begin{tabular}{|c|c|c|c|c|c|c|}
\hline \multicolumn{7}{|c|}{ Coefficients $^{\mathrm{a}}$} \\
\hline \multirow{2}{*}{\multicolumn{2}{|c|}{ Model }} & \multicolumn{2}{|c|}{ Unstandardized Coefficients } & \multirow{2}{*}{$\begin{array}{c}\text { Standardized Coefficients } \\
\text { Beta }\end{array}$} & \multirow{2}{*}{$\mathrm{T}$} & \multirow{2}{*}{ Sig. } \\
\hline & & B & Std. Error & & & \\
\hline \multirow{3}{*}{1} & Constant & 91.830 & 4.874 & & 18.839 & .000 \\
\hline & kecemasan akademis & -.423 & .100 & -.315 & -4.220 & .000 \\
\hline & Self efficacy & -.567 & .078 & -.543 & -7.270 & .000 \\
\hline & ependent Variable: $\mathrm{c}$ & lukungan s & & & & \\
\hline
\end{tabular}

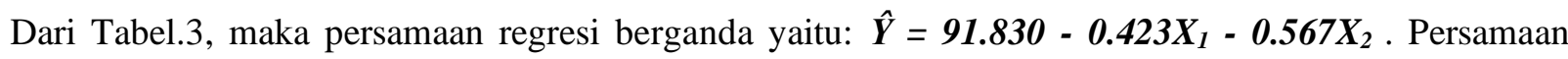
tersebut mengindikasikan nilai koefisien b (Self efficacy dan dukungan sosial) bernilai negatif, artinya kecemasan akademis dan Self efficacy memiliki hubungan terbalik. Apabila Self efficacy siswa meningkat sebesar satu satuan, maka kecemasan akademis yang mereka rasakan akan menurun sebesar 0.423 satuan. Apabila dukungan sosial yang diterima siswa meningkat sebesar satu satuan, maka kecemasan akademis yang mereka rasakan akan menurun sebesar 0.567 satuan.

Tabel 4. Uji Normalitas

\begin{tabular}{|c|c|c|}
\hline \multicolumn{3}{|c|}{ One-Sample Kolmogorov-Smirnov Test } \\
\hline \multicolumn{2}{|c|}{$\mathrm{N}$} & Unstandardized Residual \\
\hline \multirow{2}{*}{ Normal Parameters ${ }^{\mathrm{a}, \mathrm{b}}$} & & 103 \\
\cline { 2 - 3 } & Mean & .0000000 \\
\hline \multirow{3}{*}{ Most Extreme Differences } & Std. Deviation & 3.71083587 \\
\cline { 2 - 3 } & Absolute & .076 \\
\cline { 2 - 3 } & Positive & .052 \\
\hline Test Statistic & Negative & -.076 \\
\hline
\end{tabular}


763 Analisis Kecemasan Akademis Melalui Self Efficacy dan Dukungan Sosial pada Siswa SMK Jurusan Akuntansi - Shabilla Yasmin Priyanti, Mardi, Achmad Fauzi

DOI: https://doi.org/10.31004/edukatif.v3i3.440

\begin{tabular}{|c|c|c|c|}
\hline Asymp. Sig. (2-tailed) & & & .165 \\
\hline & Sig. & & .155 \\
\hline Monte Carlo Sig. (2-tailed) ${ }^{\mathrm{d}}$ & $00 \%$ Confidence Interva & Lower Bound & .146 \\
\hline & $99 \%$ Confidence Interval & Upper Bound & .164 \\
\hline a. Test distribution is Norma & & & \\
\hline b. Calculated from data. & & & \\
\hline c. Lilliefors Significance Cor & rrection. & & \\
\hline d. Lilliefors' method based o & n 10000 Monte Carlo sam & les with starti & 0000 . \\
\hline
\end{tabular}

Pada Tabel. 4 Nilai Asymp. Sig. (2-tailed) dari Unstandardized Residual menunjukan angka 0.165. Angka tersebut menunjukan nilai $\mathrm{p}>$ alpha 0.05, maka disimpulkan kuesioner yang telah diisi oleh 103 sampel berdistribusi secara normal.

Tabel 5. Uji Linearitas kecemasan akademis dengan Self efficacy

\begin{tabular}{|c|c|c|c|c|c|c|}
\hline \multicolumn{7}{|c|}{ ANOVA Table } \\
\hline & & Sum of Squares & $\mathrm{df}$ & Mean Square & $\mathrm{F}$ & Sig. \\
\hline \multirow{3}{*}{ Between Groups } & (Combined) & 728.738 & 17 & 42.867 & 1.916 & .027 \\
\hline & Linearity & 484.041 & 1 & 484.041 & 21.63 & .000 \\
\hline & Deviation from Linearity & 244.697 & 16 & 15.294 & .683 & .803 \\
\hline \multicolumn{2}{|c|}{ Within Groups } & 1902.175 & 85 & 22.379 & & \\
\hline & Total & 2630.913 & 102 & & & \\
\hline
\end{tabular}

Sumber: hasil pengolahan data peneliti

Berdasarkan Tabel. 5 deviation from linearity kecemasan akademis dengan Self efficacy sebesar 0.803, berarti nilai tersebut lebih besar dibanding alpha 0.05. Sehingga, disimpulkan kecemasan akademis dengan Self efficacy berhubungan secara linear.

Tabel 6. Uji Linearitas kecemasan akademis dengan dukungan sosial

\begin{tabular}{|c|c|c|c|c|c|c|}
\hline \multicolumn{7}{|c|}{ ANOVA Table } \\
\hline \multirow{3}{*}{ Between Groups } & Sum of Squares & df & Mean Square & F & Sig. \\
\cline { 2 - 8 } & (Combined) & 1447.340 & 21 & 68.921 & 4.717 & .000 \\
\cline { 2 - 8 } & Linearity & 976.188 & 1 & 976.188 & 66.807 & .000 \\
\hline \multicolumn{2}{|c|}{ Within Groups } & 1183.573 & 81 & 14.612 & & \\
\hline \multicolumn{2}{|c|}{ Total } & 2630.913 & 102 & & & \\
\hline
\end{tabular}

Sumber: hasil pengolahan data peneliti

Sedangkan menurut Tabel. 6 deviation from linearity pada kecemasan akademis dengan dukungan sosial sebesar 0.070. Berarti nilai tersebut lebih besar dibanding alpha 0.05. Sehingga disimpulkan kecemasan akademis dengan dukungan sosial merupakan variabel memiliki hubungan yang linear.

Tabel 7. Uji -t

\begin{tabular}{|c|c|c|c|c|c|c|}
\hline \multicolumn{7}{|c|}{ Coefficients $^{\mathbf{a}}$} \\
\hline \multirow{2}{*}{ Model } & Unstandardized Coefficients & Standardized Coefficients & \multirow{2}{*}{ S } & \multirow{2}{*}{ Sig. } \\
\cline { 2 - 7 } & B & Std. Error & Beta & & 18.839 & .000 \\
\hline \multirow{2}{*}{1} & Constant & 91.830 & 4.874 & & -4.220 & .000 \\
\cline { 2 - 7 } & Self efficacy & -.423 & .100 & -.315 & -7.270 & .000 \\
\cline { 2 - 6 } & dukungan sosial & -.567 & .078 & -.543 & &
\end{tabular}




\section{a. Dependent Variable: kecemasan akademi \\ Sumber: hasil pengolahan data peneliti}

Tabel. 7 menunjukan Self efficacy memiliki t-hitung sebesar - 4.220. dan t-tabel (-1.987) dengan taraf signifikan $=0.025$. Kemudian, dukungan sosial memiliki t-hitung sebesar -7.270. t-tabel (-1.987) taraf signifikan 0.025. Hal ini berarti Self efficacy dan dukungan sosial lebih besar dari t-tabel (-1.987). Uji T disimpulkan Self efficacy berpengaruh negatif yang signifikan secara parsial terhadap kecemasan akademis. Selain itu, dukungan sosial juga berpengaruh negatif secara signifikan secara parsial pada kecemasan akademis. Pengaruh yang signifikan dapat diartikan bahwa pengaruh negatif Self efficacy serta dukungan sosial pada kecemasan akademis dapat diberlakukan untuk seluruh populasi.

Tabel 8. Uji F

\begin{tabular}{|c|c|c|c|c|c|c|}
\hline \multicolumn{7}{|c|}{ ANOVA $^{\mathrm{a}}$} \\
\hline Model & Sum of Squares & df & Mean Square & F & Sig. \\
\hline \multirow{3}{*}{1} & Regression & 1226.342 & 2 & 613.171 & 43.655 & $.000^{\mathrm{b}}$ \\
\cline { 2 - 7 } & Residual & 1404.571 & 100 & 14.046 & & \\
\cline { 2 - 7 } & Total & 2630.913 & 102 & & & \\
\hline & a. Dependent Variable: kecemasan akademi \\
\hline
\end{tabular}
b. Predictors: (Constant), dukungan sosial, Self efficacy
Sumber: hasil pengolahan data peneliti

Menurut Tabel.8, ditunjukkan F hitung $=$ 43.655. Sedangkan nila F tabel (3.09). Sehingga disimpulkan F hitung > F tabel. Pengertian ini menunjukkan bahwa Self efficacy dan dukungan sosial memiliki pengaruh signifikan terhadap kecemasan akademis secara simultan. Pengaruh signifikan dapat diartikan pengaruh negatif Self efficacy dan dukungan sosial pada kecemasan akademis dapat diberlakukan untuk seluruh populasi. Kemudian demi mengetahui kontribusi Self efficacy dan dukungan sosial untuk memprediksi kecemasan akademis, maka dilakukan uji koefisien determinasi sebagai berikut.

Tabel 9. Analisis Koefisien Determinasi

\begin{tabular}{|c|c|c|c|c|c|c|c|c|c|}
\hline \multicolumn{10}{|c|}{ Model Summary } \\
\hline \multirow[b]{2}{*}{ Model } & \multirow[b]{2}{*}{$\mathrm{R}$} & \multirow[b]{2}{*}{$\begin{array}{c}\mathrm{R} \\
\text { Square }\end{array}$} & \multirow[b]{2}{*}{$\begin{array}{l}\text { Adjusted R } \\
\text { Square }\end{array}$} & \multirow[b]{2}{*}{$\begin{array}{l}\text { Std. Error of the } \\
\text { Estimate }\end{array}$} & \multicolumn{5}{|c|}{ Change Statistics } \\
\hline & & & & & $\begin{array}{c}\text { R Square } \\
\text { Change }\end{array}$ & $\begin{array}{c}\mathrm{F} \\
\text { Change }\end{array}$ & df1 & $\mathrm{df} 2$ & $\begin{array}{c}\text { Sig. F } \\
\text { Change }\end{array}$ \\
\hline 1 & $.683^{\mathrm{a}}$ & .466 & .455 & 3.748 & .466 & 43.655 & 2 & 100 & .000 \\
\hline
\end{tabular}

Sumber: hasil pengolahan data peneliti

Dari Tabel.9 menunjukan R Square $=0.466$. Hal mana Self efficacy dan dukungan sosial memiliki kontribusi sebesar 46,6\% untuk memprediksi kecemasan akademis, sedangkan sisanya $53.4 \%$ dipengaruhi oleh faktor diluar penelitian ini.

Hasil dari penelitian sejalan oleh penelitian (Mugiarso et al., 2018), dijelaskan bahwa kecemasan yang dirasakan seseorang bisa memberikan pengaruh pada Self efficacy berupa keyakinan orang tersebut untuk menghadapi berbagai situasi. Sehingga peserta didik yang mempunyai keyakinan yang tinggi cenderung memiliki kecemasan yang lebih rendah. Penelitian yang dilakukan (Huerta et al., 2017) menjelaskan Self efficacy dapat menjadi perdiktor secara signifikan pada kecemasan yang dirasakan oleh peserta didik. Pada tahap ini dapat disimpulkan "dengan meningkatkan kepercayaan diri peserta didik dengan tersedianya strategi yang tepat, maka mereka akan mampu meningkatkan Self efficacy, hal mana akan dapat pula mengurangi kecemasan yang dialami”. 
Sejalan penelitian (Sunaryo, 2017), yaitu Self efficacy dapat membantu peserta didik untuk menentukan kegiatannya, berusaha lebih maju, lebih tekun ketika mengatasi kesulitan, serta tenang dan tidak cemas saat mengerjakan tugas-tugasnya. Begitu juga penelitian yang dilakukan (Purwanti et al., 2020), bahwa ada pengaruh kuat arah negatif Self efficacy pada kecemasan akademis. Self efficacy memiliki kontribusi sebesar 28\% untuk memprediksi kecemasan akademis yang dirasakan oleh peserta didik. Hasil penelitian (Thamrin et al., 2019) memaparkan Self efficacy peserta didik berpengaruh positif pada kecemasan akademis. Peserta didik mengalami kecemasan selama proses akademisnya adalah karena rendahnya Self efficacy yang mereka miliki. Semakin baik Self efficacy mereka maka kecemasan akademis yang mereka rasakan pun akan lebih rendah.

Penelitian ini mendukung teori yang dipaparkan Berns, yakni reaksi psikologi seperti stres, kelelahan, dan kecemasan dapat menurunkan persepsi seseorang mengenai kemampuan yang mereka miliki (Berns, 2013). Serta teori (Schwarzer, 2014) yang mengatakan bahwa peserta didik dengan tingkat Self efficacy rendah lebih rentan mengalami depresi, kecemasan, dan putus asa. Mereka merasa pesimis tidak bisa mencapai tujuannya. Penelitian yang dilakukan oleh (Ganal et al., 2020) menjelaskan dukungan sosial berpengaruh negatif terhadap kecemasan akademis. Semakin tinggi dukungan yang diterima peserta didik, baik dari orang tua, guru, maupun teman, maka akan semakin rendah kecemasan yang ia alami. Begitupula penelitian (Mahmoud et al., 2015) yang mengatakan dukungan sosial memiliki hubungan negatif dengan kecemasan. Hasil penelitian (Harandi et al., 2017) menyimpulkan ada dukungan sosial memiliki pengaruh dengan keeratan sedang dengan kecemasan. Apabila siswa menjalin komunikasi sosial yang positif dengan teman dan keluarganya, maka ia akan bisa meningkatkan perasaan aman dalam dirinya serta dapat menurunkan kecemasan yang dialami.

Selain itu (Sri Djuwitawati \& Djalali, 2015) menjelaskan bahwa ada hubungan kecemasan yang dirasakan peserta didik dengan dukungan sosial yang ia terima. Peserta didik cenderung merasa cemas ketika akan menghadapi ujian. Untuk mengatasi kecemasan tersebut dapat diberikan dukungan sosial dari orang tua, guru maupun bagian konseling sekolah. Begitupula dengan teori (Liu, 2019) yaitu dengan meningkatkan situasi sosial dan partisipasi seseorang di dalam masyarakat dapat meningkatkan kesejahteraan dan kebahagiaan seseorang. Dukungan dari teman sebaya pun dapat meningkatkan kesejahteraan dan kebahagiaan, serta menghilangkan rasa kesepian pada seseorang. Begitupula teori (LAM, 2019) yang mengatakan bahwa dukungan sosial memiliki kontribusi pada kesehatan mental seseorang. Mereka akan merasa lebih aman, dihormati, berharga, dan menikmati kegiatan mereka.

Pada penelitian (Andarini, 2020) dikatakan bahwa dukungan sosial serta Self efficacy berpengaruh signifikan secara bersama-sama pada stres akademis yang dirasakan oleh siswa. Peserta didik dengan Self efficacy tingkat tinggi lebih dapat mengurangi stres yang dialami dan meningkatkan hasil belajar, mereka juga lebih tekun, mampu mengolah emosi, mengatasi masalah serta mengatasi tekanan. Dukungan sosial dari orang tua yang tinggi juga bisa membuat peserta didik merasa dipedulikan sehingga emosi mereka akan lebih stabil dalam menghadapi berbagai kesulitan akademis. Selanjutnya penelitian (Warshawski et al., 2019) yang menyimpulkan meningkatnya Self efficacy dalam bidang akademis peserta didik, maka kecemasan yang mereka alami akan menurun. Selain itu juga dukungan sosial memiliki peran untuk mengurangi kecemasan yang dihadapi oleh peserta didik. Penelitian (Rambe, 2017) juga mengatakan apabila peserta didik menerima banyak dukungan dari orang-orang disekitarnya dan juga Self efficacy yang tinggi, maka peserta didik tersebut akan mengalami kecemasan akademis yang lebih rendah.

Namun hasil penelitian ini membantah temuan yang disimpulkan Herawati serta kesimpulan penelitian Situmorang. Pada penelitiannya Herawati memaparkan Self efficacy tidak secara signifikan berpengaruh pada kecemasan akademis, dijelaskan memiliki pengaruh signifikan terhadap kecemasan akademis adalah dukungan sosial yang diterima oleh peserta didik. Semakin tinggi dukungan sosial yang diterima peserta didik, maka akan semakin rendah kecemasan yang mereka alami (Herawati et al., 2021). Sedangkan pada penelitian (Situmorang, 2019) dijelaskan dukungan sosial tidak memiliki pengaruh yang signifikan pada kecemasan 
akademis peserta didik terutama ketika akan menghadapi ujian akhir, ditegaskan Self efficacy berpengaruh signifikan negatif pada kecemasan tersebut, kecemasan yang mereka alami akan menurun apabila self efficacy yang mereka miliki meningkat.

Maka dari hasil tersebut, penelitian ini menjadi suatu kebaruan baru dengan membuktikan bahwa self efficacy dan dukungan sosial memiliki kontribusi pada kecemasan akademis siswa kelas XII di bidang akuntansi. Dengan begitu penelitian ini berkontribusi dalam memperkuat teori yang telah ada berdasarkan pemikiran ahli maupun penelitian relevan terdahulu. Penelitian ini juga menjadi pembuktian secara empiris mengenai pengaruh dari self efficacy yang dimiliki serta dukungan sosial yang diterima oleh peserta didik dengan kecemasan akademis yang mereka rasakan. Oleh karena itu, penelitian yang telah dilakukan ini dapat menjadi acuan yang relevan dalam pengembangan penelitian terkait selanjutnya di masa depan. Keterbatasan dalam penelitian ini diantaranya adalah penelitian yang dilakukan pada sampel masih bersifat general tanpa memperhatikan gender dan faktor lainnya yang berbeda antara sampel yang satu dengan yang lainnya, dan juga populasi dalam penelitian ini masih sangat terbatas akibat keterbatasan selama pandemi COVID 19 sehingga hasil penelitian hanya dapat digeneralisasi pada populasi yang diambil.

\section{KESIMPULAN}

Dari penelitian ini menyimpulkan bahwa secara empiris merujuk kepada penelitian relevan dan konsep teori yang melandasi variabel yang diuji yaitu kecemasan akademis yang dialami oleh siswa (kelas XII akuntansi) dipengaruhi self efficacy serta dukungan sosial yang mereka terima. Self efficacy dan dukungan sosial secara signifikan berpengaruh negatif terhadap kecemasan akademis siswa akuntansi secara parsial dan simultan. Apabila siswa dengan self efficacy tinggi mereka cenderung mengalami kecemasan akademis lebih rendah. Sebaliknya apabila self efficacy siswa rendah, mereka lebih mengalami kecemasan akademis yang lebih tinggi. Bersama dengan itu pula apabila siswa menerima banyak dukungan sosial dari orang yang ada disekitarnya, maka mereka cenderung mengalami kecemasan akademis yang lebih rendah. Sebaliknya bagi siswa yang menerima sedikit dukungan sosial dari orang-orang disekitarnya, maka mereka cenderung mengalami kecemasan akademis yang lebih tinggi. Menyadari pentingnya penelitian mengenai kecemasan akademis peserta didik, peneliti merekomendasikan agar penelitian mengenai kecemasan akademis ini dapat dikembangkan secara lebih luas, baik dari segi topik penelitian maupun populasi yang digunakan. Dengan demikian, penelitian mengenai kecemasan akademis peserta didik ini dapat memberikan kontribusi positif kepada bidang pendidikan kejuruan khususnya program studi Akuntansi di sekolah kejuruan tingkat atas.

\section{REFERENCES}

Andarini, N. T. (2020). The Role of Parents' Social Support and Self-Efficacy towards Academic Stress. International Journal of Management and Humanities, 4(11), 1-6. https://doi.org/10.35940/ijmh.g0659.0741120

Anshori, I., \& Illiyyin, U. (2020). Dampak COVID-19 Terhadap Proses Pembelajaran di Mts Al-Asyhar Bungah Gresik. Islamic Management: Jurnal Manajemen Pendidikan Islam. https://doi.org/10.30868/im.v3i02.803

Anwar, M. (2015). Filsafat Pendidikan. Kencana.

Ardianto, P. (2018). Gejala Kecemasan Pada Siswa Sekolah Menengah Kejuruan. Jurnal Ilmiah Bimbingan Konseling Undiksha, 9(2), 87-91. https://doi.org/10.23887/XXXXXX-XX-0000-00

Berns, R. M. (2013). Child, Family, School, Community Socialization and Support. Wadsworth.

Brailovskaia, J., Schönfeld, P., Zhang, X. C., Bieda, A., Kochetkov, Y., \& Margraf, J. (2018). A Cross- 
767 Analisis Kecemasan Akademis Melalui Self Efficacy dan Dukungan Sosial pada Siswa SMK Jurusan Akuntansi - Shabilla Yasmin Priyanti, Mardi, Achmad Fauzi

DOI: https://doi.org/10.31004/edukatif.v3i3.440

Cultural Study in Germany, Russia, and China: Are Resilient and Social Supported Students Protected

Against Depression, Anxiety, and Stress? Psychological Reports, 121(2), 265-281. https://doi.org/10.1177/0033294117727745

Chou, M. H. (2019). Predicting Self-Efficacy in Test Preparation: Gender, Value, Anxiety, Test Performance, and Strategies. Journal of Educational Research, 112(1), 61-71. https://doi.org/10.1080/00220671.2018.1437530

Cintya, N. K., \& Supriyadi. (2020). Peran Kepercayaan Diri dan Dukungan Sosial terhadap Kecemasan Komunikasi pada Orang Tuli di Denpasar. Jurnal Psikologi Udayana, 2, 49-59. https://ocs.unud.ac.id/index.php/psikologi/article/view/63505

Dewi, W. A. F. (2020). Dampak COVID-19 terhadap Implementasi Pembelajaran Daring di Sekolah Dasar. Edukatif: Jurnal Ilmu Pendidikan, 2(1), 55-61. https://doi.org/10.31004/edukatif.v2i1.89

Fitria, L., \& Ifdil, I. (2020). Kecemasan Remaja pada Masa Pandemi COVID-19. EDUCATIO: Jurnal Pendidikan Indonesia, 6(1), 1. https://doi.org/10.29210/120202592

Ganal, N. N., Guiab, M. R., \& Strategi, P. (2020). Teaching Strategies and Social Support on Students ' Mathematics Achievement, Attitude, and Anxiety. ATIKAN: Jurnal Kajian Pendidikan, 10(1), 1-22. https://doi.org/10.2121/atikan-journal.v10i1.1320.g1147

Habibullah, M., Hastiana, Y., \& Hidayat, S. (2019). Kecemasan Mahasiswa Dalam Menghadapi Seminar Hasil Skripsi Di Lingkungan FKIP Universitas Muhammadiyah Palembang. BIOEDUKASI: Jurnal Pendidikan Biologi, 10(1), 36. https://doi.org/10.24127/bioedukasi.v10i1.2015

Halim, F. (2019). Pengaruh Dukungan Sosial Teman Sebaya dan Kepercayaan Diri Terhadap Kecemasan Belajar Mahasiswa pendidikan Dasar. PiJIES: Pendagogik Journal of Islamic Elementary School, 2(2), 129-146. https://doi.org/10.24256/pijies.v2i2.917

Hanani, S. (2017). Sosiologi Pendidikan Keindonesiaan (2nd ed.). Ar-Ruzz Media.

Harandi, T. F., Taghinasab, M. M., \& Nayeri, T. D. (2017). The Correlation Of Social Support With Mental Health: A Meta-Analysis. Electronic Physician, 9(9), 5212-5222. https://doi.org/10.19082/5212

Herawati, M., Muhid, A., \& Hamdani, A. S. (2021). Self-Efficacy, Social Support, Academic Flow, and Math Anxiety among Islamic Senior High School Students. Psympathic: Jurnal Ilmiah Psikologi, 7(2), 315 326. https://doi.org/10.15575/psy.v7i2.8474

Huerta, M., Goodson, P., Beigi, M., \& Chlup, D. (2017). Graduate Students As Academic Writers: Writing Anxiety, Self-Efficacy And Emotional Intelligence. Higher Education Research and Development, 36(4), 716-729. https://doi.org/10.1080/07294360.2016.1238881

Iriana, F. (2016). Pengembangan Kurikulum: Teori, Konsep, dan Aplikasi (1st ed.). Parana Ilmu.

Iswahyudi, Yohana, C., \& Mardi. (2019). Impact Self-Efficacy and Supervisor Support on Transfer of Training: Two Stage Approach Analysis. Jurnal Pendidikan Ekonomi \& Bisnis, 7(5), 47-60. https://doi.org/10.21009/JPEB.007.1.5

Jatira, Y., \& Neviyarni, S. (2021). Fenomena Stress dan Pembiasaan Belajar Daring Dimasa Pandemi Covid19. Edukatif: Jurnal Ilmu Pendidikan, 3(1), 35-43. https://doi.org/10.31004/edukatif.v3i1.187

KPAI. (2020). Survei Pelaksanaan Pembelajaran Jarak Jauh (PJJ) dan Sistem Penilaian Jarak Jauh Berbasis Pengaduan KPAI. KPAI. http://billyantoro.com/wp-content/uploads/2020/06/Paparan-Survei-PJJKPAI.pdf

Kurniawan, A. W., \& Puspitaningtyas, Z. (2016). Metode Penelitian Kuantitatif. In Philosophy of Science (Vol. 4, Issue 4). Pandiva Buku.

LAM, B. (2019). Social Support Giving and Teacher Development. In Springer. The Education University of Hong Kong.

Liu, S. (2019). Social Support Networks, Coping and Positive Aging Among the Community-Dwelling 
768 Analisis Kecemasan Akademis Melalui Self Efficacy dan Dukungan Sosial pada Siswa SMK Jurusan Akuntansi - Shabilla Yasmin Priyanti, Mardi, Achmad Fauzi

DOI: https://doi.org/10.31004/edukatif.v3i3.440

Elderly in Hong Kong. In Huazhong University of Science and Technology Press. Springer.

Mahmoud, J. S. R., Staten, R. T., Lennie, T. A., \& Hall, L. A. (2015). The Relationships of Coping, Negative Thinking, Life Satisfaction, Social Support, and Selected Demographics With Anxiety of Young Adult College Students. Journal of Child and Adolescent Psychiatric Nursing, 28(2), 1-12. https://doi.org/10.1111/jcap.12109

Mansyur, A. R. (2020). Dampak COVID-19 Terhadap Dinamika Pembelajaran Di Indonesia. Education and Learning Journal, 1(2), 113. https://doi.org/10.33096/eljour.v1i2.55

McDonnell, R. (2014). Creative and Social Support in Mental Health: Service Users' perspectives. Palgrave Macmillan.

Mugiarso, H., Setyowani, N., \& Tedra, L. B. (2018). Self-Efficacy dan Persistensi Mahasiswa ketika Mengerjakan Skripsi Ditinjau dari Kecemasan Akademik. TERAPUTIK: Jurnal Bimbingan Dan Konseling, 1(3), 171. https://doi.org/10.26539/1370

OECD. (2018). What 15-Year-Old Students in Indonesia Know and Can Do. Programme for International Student Assessment (PISA). http://www.oecd.org/pisa/ Data

Oktawirawan, D. H. (2020). Faktor Pemicu Kecemasan Siswa dalam Melakukan Pembelajaran Daring di Masa Pandemi Covid-19. Jurnal Ilmiah Universitas Batanghari Jambi, 20(2), 541. https://doi.org/10.33087/jiubj.v20i2.932

Prayogi, F., Muslihati, \& Handarini, D. M. (2017). Hubungan Self Efficacy, Optimism, Social Support Dan Psychological Well-Being Peserta Didik SMK. Jurnal Pendidikan: Teori, Penelitian, Dan Pengembangan, 2 Nomor 4(April), 508-515. https://doi.org/10.17977/jptpp.v2i4.8770

Purwanti, I. Y., Wangid, M. N., \& Aminah, S. (2020). Self-Efficacy and Academic Anxiety of College Students. Advances in Social Science, Education and Humanities Research, 462, 276-279. https://doi.org/10.2991/assehr.k.200814.060

Qudsyi, H., \& Putri, M. I. (2016). Self-efficacy and Anxiety of National Examination among High School Students. Procedia: Social and Behavioral Sciences, 217, 268-275. https://doi.org/10.1016/j.sbspro.2016.02.082

Raharjayanti, Y. (2019). Dukungan Sosial Keluarga dan Self Efficacy Siswa SMP dalam Menghadapi Ujian Nasional. Jurnal PROMKES, 7(2), 133. https://doi.org/10.20473/jpk.v7.i2.2019.133-143

Rambe, Y. S. (2017). Hubungan Self Efficacy Dan Dukungan Sosial Dengan Kecemasan Siswa Menghadapi Ujian Nasional Berbasis Komputer (UNBK) Di SMK Swasta PAB 12 Saentis. Analitika, 9(1), 60-68. https://doi.org/10.31289/analitika.v9i1.740

Reid, G. M., Holt, M. K., Bowman, C. E., Espelage, D. L., \& Green, J. G. (2016). Perceived Social Support and Mental Health among First-Year College Students with Histories of Bullying Victimization. Journal of Child and Family Studies, 25(11), 3331-3341. https://doi.org/10.1007/s10826-016-0477-7

Safiany, A., \& Maryatmi, A. S. (2018). Hubungan Self Efficacy dan Dukungan Sosial Teman Sebaya dengan Stres Akademik pada Siswa-Siswi Kelas XI pada SMA Negeri 4 Jakarta Pusat. IKRAITH Humanira: Jurnal Sosial Dan Humaniora, 2(3), 87-95. http://journals.upi-yai.ac.id/index.php/ikraithhumaniora/article/view/362

Sagita, D. D., Daharnis, D., \& Syahniar, S. (2017). Hubungan Self Efficacy, Motivasi Berprestasi, Prokrastinasi Akademik Dan Stres Akademik Mahasiswa. Bikotetik (Bimbingan Dan Konseling: Teori Dan Praktik), 1(2), 43. https://doi.org/10.26740/bikotetik.v1n2.p43-52

Sari, A., \& Sumiati, A. (2016). Hubungan Antara Dukungan Sosial Dengan Efikasi Diri Pada Siswa Kelas X Akuntansi Di SMK Bina Pangudi Luhur Jakarta. Econosains Jurnal Online Ekonomi Dan Pendidikan, 14(2), 16-25. https://doi.org/10.21009/econosains.0142.02

Schwarzer, R. (2014). Self-Efficacy: Thought Control of Action. Routledge. 

Akuntansi - Shabilla Yasmin Priyanti, Mardi, Achmad Fauzi DOI: https://doi.org/10.31004/edukatif.v3i3.440

Situmorang, N. Z. (2019). The Correlation of Self-Efficacy and Peer Support towards Anxiety Preceding Final Examinations Faced by 9th Graders in Yogyakarta. Humanities and Social Sciences Reviews, 7(3), 169175. https://doi.org/10.18510/hssr.2019.7326

Sri Djuwitawati, \& Djalali, M. A. (2015). Percaya Diri, Dukungan Sosial dan Kecemasan Siswa Menghadapi Seleksi Perguruan Tinggi. PERSONA: Jurnal Psikologi Indonesia, 4(3), 296-303. https://doi.org/10.30996/persona.v4i03.724

Stewart, G., Seifert, T. A., \& Rolheiser, C. (2015). Anxiety and Self-efficacy's Relationship with Undergraduate Students' Perceptions of the use of Metacognitive Writing Strategies. The Canadian Journal of the Scholarship of Teaching and Learning, 6(1). https://doi.org/10.5206/cjsotlrcacea.2015.1.4

Sunaryo, Y. (2017). Pengukuran Self-Efficacy Siswa dalam Pembelajaran Matematika di MTs N 2 Ciamis. Teorema, 1(2), 39. https://doi.org/10.25157/.v1i2.548

Suputra, I. G. D., \& Susilawati, L. K. P. A. (2019). Peran Efikasi Diri dan Kecemasan Akademis terhadap Self-Regulated Learning pada Mahasiswa Program Studi Sarjana Psikologi Fakultas Kedokteran Universitas Udayana. Jurnal Psikologi Udayana, 6(3), 1293-1302. https://ojs.unud.ac.id/index.php/psikologi/article/view/52486

Sutarsyah, C. (2016). Pendidikan di Indonesia: Permasalahan dan Solusi. Media Akademi.

Syah, R. H. (2020). Dampak Covid-19 pada Pendidikan di Indonesia: Sekolah, Keterampilan, dan Proses Pembelajaran. SALAM: Jurnal Sosial Dan Budaya Syar-I, 7(5). https://doi.org/10.15408/sjsbs.v7i5.15314

Syahrum, \& Salim. (2014). Metodologi Penelitian Kuantitatif(R. Ananda (ed.)). Citapustaka Media.

Syamsurijal, \& Sarwan. (2021). Kondisi Psikologis Mahasisawa PGSD Universitas Muhammadiyah Buton (UMB) dalam Pelaksanaan Pembelajaran Daring di Masa Pandemi. Edukatif: Jurnal Ilmu Pendidikan, 3(1), 220-226. https://doi.org/10.31004/edukatif.v3i1.290

Thamrin, T., Akbar, M., \& Tola, B. (2019). Self-Efficacy, Academic Anxiety, and Self-Regulated Learning on Mathematics Achievement at Vocational High School. ICTES. https://doi.org/10.4108/eai.21-112018.2282033

Wagetama, I. D., Dariyo, A., \& Debor, B. (2017). Hubungan antara Kecemasan Matematika dan Self-Efficacy dengan Hasil Belajar Matematika Siswa SMA X Kota Palangka Raya. Muara Ilmu Sosial, Humaniora, Dan Seni, 1 no.2, 556-568. https://doi.org/10.24912/jmishumsen.v1i2.799

Warshawski, S., Bar-Lev, O., \& Barnoy, S. (2019). Role of Academic Self-efficacy and Social Support on Nursing Students' Test Anxiety. Nurse Educator, 44(1), E6-E10. https://doi.org/10.1097/NNE.0000000000000552 